\title{
THE DESCENDANTS OF ANGOLANS AND LUSO-ANGOLANS IN THE LISBON METROPOLITAN AREA: ASPECTS OF THEIR INTEGRATION ${ }^{1}$
}

DORA POSSIDÓNIO ${ }^{2}$

\begin{abstract}
The focus of this paper is on the integration of immigrants and ethnic minorities, with special emphasis being placed on the descendants of Angolans and Luso-Angolans that live in the Lisbon Metropolitan Area.

Throughout the paper, we seek to identify the factors that influence the integration of the descendants of immigrants and to assess the degree of success of these individuals in their process of integration in the Portuguese society.

Its first section is a brief theoretical discussion of the issue of the integration of immigrants and ethnic minorities. In the rest of the paper, an assessment is made of the degree of success of these individuals in their process of integration, by way of indicators such as their area of residence, school performance, professional status and the "identity/culture of opposition" binomial. Individual exceptions notwithstanding, our findings corroborate the existence of severe, widespread difficulties in the integration process of these individuals.
\end{abstract}

Key words : Immigrant integration, Descendents of Angolans, Lisbon Metropolitan Area.

Resumo-Descendentes de angolanos e de luso-angolanos na Área MetroPOLITANA DE LISBOA: ALGUNS ASPECTOS DA SUA INSERÇãO. O presente artigo aborda a temática da inserção de imigrantes e minorias étnicas, centrando-se no processo de inserção de um grupo constituído por descendentes de angolanos e de luso-angolanos residentes na Área Metropolitana de Lisboa.

Partindo-se do pressuposto que estes indivíduos, devido à sua condição de descendentes de imigrantes ou minorias étnicas estão em situação de desvantagem face aos jovens de origem portuguesa, herdando condicionantes vários que se afirmam como dificuldades à sua inserção, estabeleceram-se como objectivos a identificação de factores que influenciam a inserção dos descendentes de

1 This paper is based on the author's Master's thesis in Human Geography and Local and Regional Planning, entitled "Descendentes de Angolanos e de Luso-Angolanos na Área Metropolitana de Lisboa: Inserção Geográfica e Social" and has been written within the ambit of the Project "Reinventing Portuguese Metropolises: Migrants and Urban Governance" (FCT/POCTI 38599/GEO/ 2001).

2 Geographer. Rua Cidade de Benguela, Lote 292-B, 3. ${ }^{\circ}$ Esq., 1800-071 Lisboa. Tel.: 968071183. 
imigrantes e a avaliação de alguns aspectos da inserção na sociedade portuguesa destes indivíduos.

Num primeiro ponto apresenta-se uma discussão teórica da temática da inserção dos imigrantes e minorias étnicas. Determinou-se que os factores que influenciam o sucesso da inserção dos descendentes dos imigrantes, tal como no caso dos próprios imigrantes, são múltiplos, encontrando-se divididos em dois grandes grupos: os que correspondem às condições existentes na sociedade de acolhimento e os que se relacionam com as características pessoais dos indivíduos em questão e das suas famílias. Estes vários factores conjugam-se para cada indivíduo e condicionam o sucesso do processo de inserção desse indivíduo.

Seguidamente, a inserção foi avaliada através da sua relação com o local de residência, o sucesso escolar/profissional e o binómio identidade/cultura de oposição, comprovando-se, apesar de diferenças entre os indivíduos, a existência de um quadro geral marcado por dificuldades de inserção. Verificou-se existir uma sobre-representação de descendentes de angolanos e de luso-angolanos em bairros degradados/estigmatizados, de habitação social e de barracas, níveis de insucesso escolar elevados e ausência de indícios significativos de mobilidade profissional ascendente. Por outro lado, constatou-se haver uma integração dos descendentes de angolanos num grupo de bairro e numa cultura juvenil negra que, caso tenha uma componente de oposição à sociedade muito elevada ou se for associada pela população portuguesa à marginalidade, constitui um factor adicional de dificuldade à inserção, para além de ser um sintoma do insucesso dessa mesma inserção.

Palavras-chave : inserção; descendentes de imigrantes; angolanos; Área Metropolitana de Lisboa.

\section{INTRODUCTION}

The phenomenon of immigration is becoming increasingly important in present-day Portugal - especially in its major cities, and particularly in the city of Lisbon and its metropolitan area. According to the last population census, $55.3 \%$ of the foreigners presently residing in Portugal live in the Greater Lisbon and Setúbal Peninsula NUT's, accounting for 5.1\% and $3.7 \%$ of the total resident population, respectively.

The longest-standing immigrant communities - the Angolans and the Cape Verdeans -, which have been present in the country for nearly three decades, can be divided into (three) generations. Despite the relevance of these communities, in terms of both their dimension and the time they have been in the country, the descendants of these immigrants have been subject to little academic attention and many fundamental questions - e.g., how many are they, where and in what conditions do they live in, what are their expectations - remain in many cases unanswered. The aim of this paper is to provide a modest contribution to the understanding and knowledge of one of these groups that make up the Portuguese society.

Considering that these individuals, due to being the descendants of immigrants or ethnic minorities, can be regarded as being in a situation of disadvan- 
tage with regard to those of Portuguese descent and thus inherit a series of factors that constrain their integration, this paper seeks to explore two main aspects:

- To identify the factors that influence the integration of the descendants of immigrants and ethnic minorities;

- To assess and explain certain aspects of these individuals' integration in the host society and territory.

\section{CONSTRAINTS TO THE PROCESS OF INTEGRATION OF THE DESCENDANTS OF IMMIGRANTS}

The goal of this section, largely based upon a review of the literature on the issue of the integration of immigrants and ethnic minorities, is to identify the main types of factors that constrain the immigrants and their descendants in their process of adaptation to the hosting society.

First of all, it is important to stress that integration should be regarded as a complex, multifaceted process that takes place at a number of different levels that, though influencing each other, are different from one another and can present different degrees of intensity. The focus of this paper is on social integration and, consequently, the main goal is to understand the position of these individuals in society.

On the subject of economic mobility, PoRTEs (1997 and 1999) maintains that two different types of forces largely determine the degree of success of the immigrants, in their integration process: the general processes and features of the hosting society and the individual skills and characteristics of the immigrants. However, it is our belief that this also holds in the case of social integration. The following figure (Fig. 1) summarises the main forces that influence the process of integration of the immigrants and ethnic minorities.

This figure builds on the assumption that, not unlike in the case of the immigrants themselves, there are numerous factors that influence the degree of success of the descendants of immigrants in their process of integration. These factors can be conceptually divided into two major groups: those having to do with the existing conditions in the host society; and the personal characteristics and resources of the individuals and their families.

The former are external to the individuals and largely outside their control. Despite their quite diverse nature, these factors can be grouped into three major types:

- the prevalent policies in the host countries, particularly those that affect the migrant groups in a direct manner;

- the public stance with regard to the various ethnic groups;

- the characteristics of the members of the ethnic community that are already in the country. 


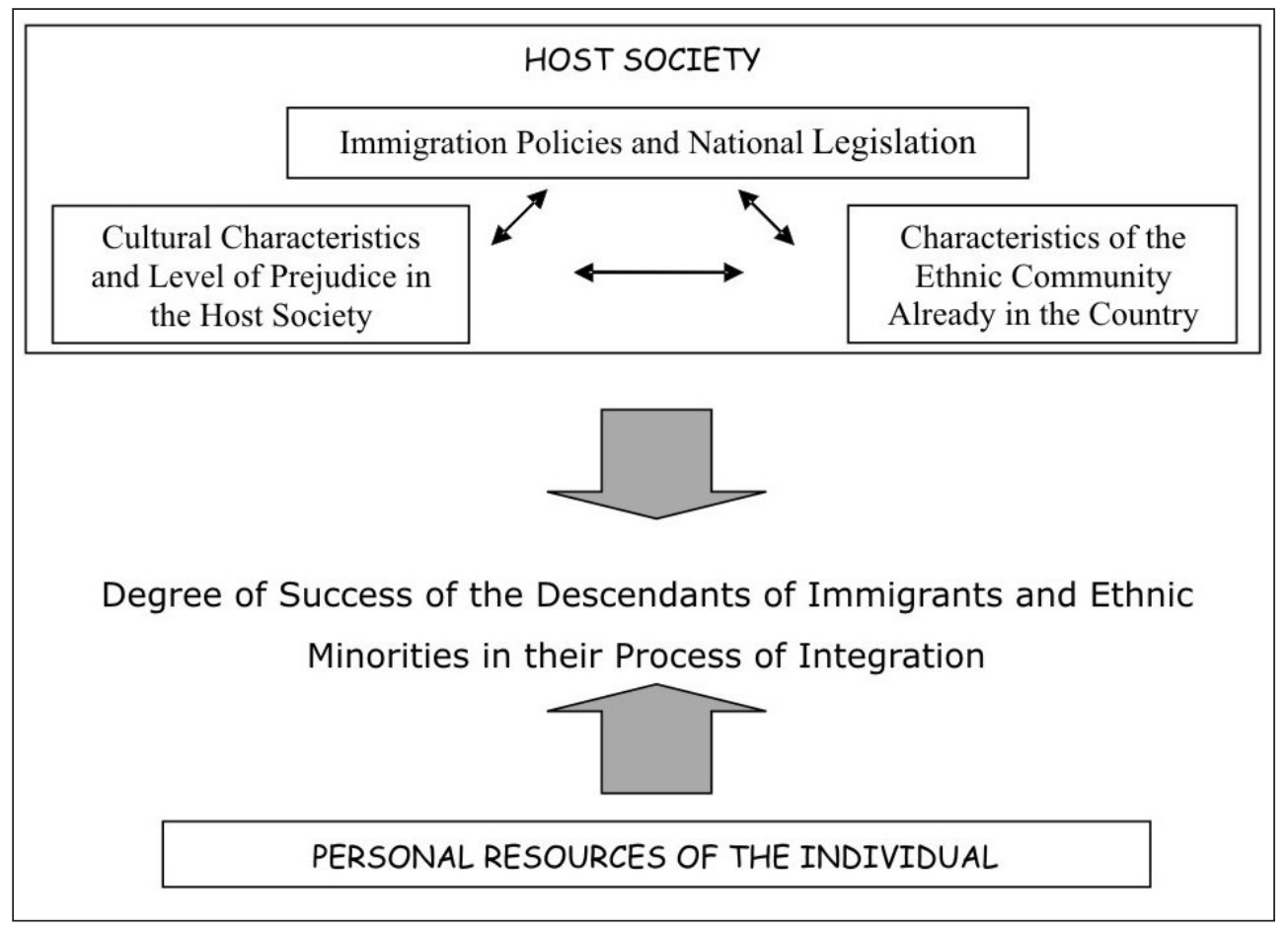

Figure 1 - Factors Affecting the Degree of Success of the Immigrants and Ethnic Minorities in their Process of Integration in the Host Society.

Figura 1 - Factores intervenientes no sucesso do processo de inserção dos imigrantes e minorias étnicas na sociedade de acolhimento.

Both government policies and the legal framework are a reflection of the ideological parameters of the State and determine the conditions of access to such fundamental and structuring aspects as citizenship itself, thus defining the rights and obligations of the individuals.

In the case of the Angolan community, we find descendants of immigrants that are Portuguese citizens (some of which were not born in Portugal) alongside others that are not, despite having been born in the country. The latter are considered as foreigners for all intents and purposes and their rights and obligations are a direct consequence of this fact.

On the other hand, the level of tolerance and openness with regard to the various ethnic groups on the part of the civil society of the host country also has a very strong influence upon the degree of success of these individuals in their process of integration. Thus, the set of cultural characteristics, values and prejudices of the host society can in fact render even harder a process that is already quite complex to begin with. Ethnic differences are often a source of 
discrimination, leading to phenomena of inequality of opportunities (in the economic, social status and professional fields) and social exclusion on the part of the autochthonous population, its institutions and its representatives.

Usually, the more visible the physical and cultural differences between the immigrants and the members of the host society, the more relevant this aspect is as a source of discrimination. Individuals whose phenotypic and cultural characteristics differ the most from the standard in the Portuguese society are those that are most often victims of prejudice. The integration process of the individuals of Angolan descent - and, more generally, those of non-European origin - is thus somewhat harder, due to the fact that the colour of their skin makes them extremely "visible" and liable to being "labelled" by the autochthonous population, even when they are in fact Portuguese citizens.

Even though the general level of openness in society is correlated with the existent policies and legislation, the relation between these two factors is not straightforward. In some instances, non-white individuals that are Portuguese citizens and/or legal immigrants can experience greater discrimination than the undocumented white immigrants, who are usually well accepted by the autochthonous population despite being illegally in the country.

On the other hand, it is important to add that the level of openness in the host society interacts with the personal characteristics and resources of the individual, who may or may not be able to minimise the level of discrimination that he/she is faced with. In other words, we might say that discrimination can be a bigger problem in certain cases, depending, among other things, on the access to information, financial resources and academic and professional qualifications of the individual, which can guarantee his/her successful integration and allow for some protection against this type of difficulty.

The third type of factors in this category has to do with the resources and degree of organisation of the ethnic community to which the individual belongs. Unlike the case of the actual immigrants, the most important role played by the ethnic community with regard to the descendants of immigrants does not occur during the period immediately after entering the country - after all, most were born in Portuguese soil. However, the role of the ethnic community is nonetheless very important, insofar as the economic and/or cultural resources that the community makes available to its members can prove extremely helpful in facilitating their upward social and economic mobility.

The second major group of factors that determine the success of the descendants of immigrants in their integration process consists of the personal resources of the individuals and their families, which render them more or less capable of adapting and of taking advantage of the opportunities that are placed before them. The skills and personality traits of the individuals can thus work either for or against their successful integration. However, these traits and skills are strongly influenced by those of their families, which, in turn, are the result of the combined sum of those of the members of the family. The descendants of immigrants inherit the success/failure of their parents' integration, by way of 
aspects such as their place of residence and their families socio-economic status (singled out by Zhou (1997) as the most important factor of all), and their opportunities and prospects for successful integration can be constrained by their parents' previous achievements in this field.

The combination of these two major groups of intertwining and mutually influencing factors either constrains or facilitates the integration of the individuals. While the former play an essential role in determining how successful the immigrants and ethnic minorities are in their process of integration as members of a given community, the latter largely explain the differences in the degree of success achieved by the various members of the same community.

\section{THE ANGOLAN COMMUNITY AND THEIR DESCENDANTS}

This particular case-study focuses on the descendants of Angolan and LusoAngolan immigrants (the former consisting of Portuguese citizens of Angolan descent, usually mestizos, who arrived in Portugal following the process of decolonisation and as a consequence of that process ${ }^{3}$ ) that live in the Lisbon Metropolitan Area ${ }^{4}$. Throughout this paper, the notion of "descendants of immigrants" is used quite loosely and includes all the individuals, regardless of their place of birth, for whom at least one of the parents is/was a member of the Angolan ethnic community ${ }^{5}$. Consequently, for the purpose of this research, we

3 This definition of "Luso-Angolans" has been adapted from MAcHADO (1994). The reason why we have chosen to include the Luso-Angolans in this research has to do with the fact that it was these individuals that traditionally laid the foundations for the migration flows from Angola to Portugal and subsequently ensured the consolidation and persistence of these flows. Since their role within the Angolan community is thus quite fundamental, it would not make much sense to exclude them from the object of this research. Moreover, the fact (confirmed during the course of our empirical research) that the children of Angolan immigrants and those of Luso-Angolans maintain close contacts with each other has also come to validate this methodological decision. It is worth noting that Angola, and to a lesser extent Mozambique, were the former Portuguese colonies in Africa in which the largest numbers of Portuguese settlers could be found during the colonisation period and, thus, were also those where there were the highest levels of racial miscegenation, due to the significant number of marriages between Angolans and Portuguese settlers.

${ }^{4}$ Our research has focused solely on the Angolans and descendants of Angolan who reside in the LMA, due to this being, by and large, their main area of settlement. According to the Foreigners and Borders Office (SEF), 82.1\% of the Angolans that had residence permits in 2001 lived in the Lisbon and Setúbal districts. In turn, the 2001 Population Census indicated that $74.7 \%$ of the Angolan citizens living in Portugal resided in the Greater Lisbon and Setúbal Peninsula areas (which are roughly the same as the LMA, but for the fact that the latter also include the Azambuja and Mafra municipalities).

5 "An ethnic group is one whose members are conscious of their common cultural identity", which in turn is made up of a set of cultural values and norms that set them apart from other groups in the same social setting (Rocha-Trindade; 1995: 367). Guy Michaud (1978), quoted in AlbuQUERQUE; FERREIRA \& VIEGAS (2000), indicates the following elements as defining an ethnic group: language, territory, a "culture" in the ethnologic sense of the word, the conscience of belonging to the group and the will to live in community. 
have also taken into account those individuals that arrived in the country in their childhood or early adolescence, regardless of whether or not they are considered as foreigners by the Portuguese law. The decision to include these individuals derives from the fact that their process of primary socialisation took place in Portugal, as was the case for the children of immigrants that were born in the country. This is the country where they were brought up, where they established their network of social relations and, thus, where they face a series of problems and difficulties that are shared by the other descendants of immigrants. For this reason, in what regards the impact of the migration process upon their lives, they have much more in common with the individuals that were born in this country than with the group to which their parents belong.

The history of Angolan emigration differs considerably from the traditional economically-driven emigration, since it is closely linked with social-political factors such as the social instability and the climate of insecurity experienced in their home country (naturally, family reunification and economic reasons add to these factors). The available statistical data shows that the Angolan community has a number of characteristics that set them apart from the immigrant communities from the other Portuguese-Speaking African Countries (PALOP), particularly the Cape Verdeans. However, these statistical differences (it is worthy of mention that the various data sources only take into account the citizens of these countries) have slowly but steadily been decreasing in intensity and the characteristics of the Angolan community have increasingly come to resemble the typical characteristics of the economic migration flows originating in Africa - young population, over-representation of labour migrants, low levels of formal qualifications and predominance of occupations in unskilled activity sectors such as construction, house cleaning and cafés and restaurants (BAGANHA; FERRÃo; MALHEIROS, 2002).

According to SEF (the Foreigners and Borders Office) data included in the Demographic Statistics Report of the National Institute of Statistics (INE), there were 22,630 Angolan citizens, holding residence permits, living in the country by 2001, making this the third most numerous foreign community in Portugal (after the Cape Verdeans and the Brazilians). In turn, the last Population Census took account of 37,014 Angolan citizens living in the country for over a year, regardless of their legal status. According to this latter source, the Angolans are the most numerous foreign community in Portugal (see Table 1).

Despite the differences between the data from these two sources ${ }^{6}-$ which in fact should not be directly compared, since they take account of two different statistical populations, we find that the Angolan community in Portugal has

6 One of the possible reasons behind these significant differences has to do with the considerable number of undocumented Angolans (as in fact is the case for all the other African communities), who are included in the INE Population Census, but not in the SEF data. Indeed, the extraordinary legalisation campaigns that took place in 1992-93 and 1996 confirmed the high percentage of undocumented immigrants among the Angolans. 
Table 1 - The 5 Most Numerous Nationalities in 2001 (SEF and INE data).

Quadro $1-N .^{\circ}$ de estrangeiros das 5 principais nacionalidades em 2001 segundo o SEF e o INE.

\begin{tabular}{lrrr}
\hline & $\mathbf{2 0 0 1}$ & $\mathbf{1 9 9 1}$ & \% Increase 1991-01 \\
Foreigners and Borders Office & & & \\
\hline Cape Verde & 49,930 & 29,743 & 67.9 \\
Brazil & 23,541 & 12,678 & 85.7 \\
Angola & 22,630 & 5,738 & 294.4 \\
Guinea-Bissau & 17,580 & 4,770 & 268.6 \\
United Kingdom & 14,952 & 8,912 & 67.8 \\
Total no. of foreigners & 223,602 & 113,978 & 96.2 \\
\hline Population Census & & & \\
\hline Angola & 37,014 & 9,368 & 295.1 \\
Cape Verde & 33,145 & 15,714 & 110.9 \\
Brazil & 31,869 & 13,508 & 135.9 \\
Guinea-Bissau & 15,824 & 3,162 & 400.4 \\
France & 15,359 & 13,742 & 11.8 \\
Total no. of foreigners & 226,715 & 106,571 & 112.7 \\
\hline
\end{tabular}

SourCE: INE, Demographic Statistics and 2001 Population Census.

FONTE: INE, Estatísticas Demográficas e Censos 2001.

increased significantly: according to either source, the number of its members has practically tripled in just ten years. This fact means that increasingly more Angolans are arriving in the country.

No statistical data are available that enable us to pinpoint the descendants of Angolans and Luso-Angolans from the rest of the community. However, the analysis of the age structure of the Angolan citizens living in Portugal at the time of the 2001 Population Census shows that the young people within the working-age group predominate $(72.6 \%$ of the individuals are aged between 15 and 44), whereas the percentage of elderly people is quite low and the percentage of youths under the age of 15 is above both that or Portugal as a whole and that for the whole of the PALOP countries (see Table 2). The percentage of under-15's experienced a slight decrease between 1991 and 2001, which was in part due to the intensification of the labour migration flows in the 1990 's that is manifest in the increase in the percentage of the individuals in the 25-44 age group.

The large percentage of youths among the Angolan immigrant population indicates that the number of the descendants of Angolans and Luso-Angolans is probably quite significant (albeit undetermined). Moreover, the fieldwork ${ }^{7}$ that

7 A survey was conducted during the 2000/2001 school year that included students for whom at least one of the parents was a member of the Angolan ethnic community, regardless of their place of birth, provided that their arrival in the country took place before the age of 12 and that they have been living in Portugal for at least 11 years. This survey was carried out in 21 public elementary and 
Table 2 - Age Structure of the Angolans, PALOP citizens, Foreign Population and Total Resident Population of Portugal.

Quadro 2 - Estrutura etária da população angolana, dos PALOP, dos estrangeiros e da totalidade da população residente em Portugal.

\begin{tabular}{cccccc}
\hline Age groups & $\begin{array}{c}\text { Angola (\%) } \\
\text { 2001 }\end{array}$ & $\mathbf{1 9 9 1}$ & $\mathbf{2 0 0 1}$ & $\begin{array}{c}\text { PALOP (\%) } \\
\text { Foreign Population (\%) }\end{array}$ & $\begin{array}{c}\text { Portugal (\%) } \\
\mathbf{2 0 0 1}\end{array}$ \\
\hline $0-14$ & 17.2 & 18.8 & 15.2 & 13.9 & 16.0 \\
$15-24$ & 23.4 & 38.8 & 20.0 & 19.3 & 14.3 \\
$25-44$ & 49.2 & 32.4 & 49.1 & 47.8 & 29.7 \\
$45-64$ & 7.6 & 7.3 & 12.3 & 14.1 & 23.6 \\
+65 & 2.7 & 2.7 & 3.3 & 4.9 & 16.4 \\
Total & 100.0 & 100.0 & 100.0 & 100.0 & 100.0 \\
Ageing Index & 0.15 & 0.14 & 0.22 & 0.35 & 1.02 \\
\hline
\end{tabular}

SOURCE: INE, 1991 and 2001 Population Census.

FONTE: INE, Censos 1991 e 2001.

we have carried out has shown that it is a highly heterogeneous group in terms of citizenship, place of birth, age at the time of arrival in the country (in the case of those that were not born in Portugal), area of residence, type of dwelling and strength of the ties binding them to their country of origin.

\section{ASPECTS OF THE INTEGRATION OF THE DESCENDANTS OF ANGOLANS AND LUSO-ANGOLANS}

Among the aspects that can be used as indicators of the degree of success of the immigrant communities in their process of integration, three in particular stand out: the area of residence, school performance (in the case of the youths) and professional status (in the case of those that are active).

\section{Area of Residence}

The area of residence provides a good indication of the level of integration of the individual in society, since it is a reflection of the financial wealth of the family, and provides clues with regard to other characteristics that are usually closely associated with the former, such as the level of schooling and socialprofessional status. It is also an important indicator, insofar as it plays a crucial

high schools in 5 municipalities of the LMA. Besides including a series of questions that aimed to assess the opinion of the individuals on a number of issues, the questionnaire also sought to allow for a characterisation of their family members. Hence, in addition to the 167 individuals that were interviewed, 195 others were characterised, who were relatives of the former and fulfilled the aforementioned conditions required to be considered as descendants of immigrants. The total number of descendants of Angolans and Luso-Angolans included in the survey was 429. 
role in defining the network of personal relations of the individual. In the specific case of the youths, it is extremely common for them to go to schools in the vicinity of their place of residence and to maintain the majority of their interpersonal contacts with people from the same area.

Largely as a consequence of their scarce financial resources, the ethnic minorities and the immigrant families are clearly over-represented in the marginalized areas of the urban territory, such as slums, social housing areas and run-down neighbourhoods. The Angolan community is not an exception.

Looking at Figure 2, in which we have plotted the location quotients ${ }^{8}$ of the Angolans living in the various freguesias (parishes) of the LMA, we find that, more often than not, the values are highest (indicating a significant presence of Angolans) in the freguesias where the best-known socially problematic areas are located. Such are the cases of the Sacavém freguesia (where the Quinta do Mocho neighbourhood ${ }^{9}$ is located) the Vale da Amoreira freguesia in the Moita municipality (where we find the social housing neighbourhood with the same name), and the freguesia of Monte Abraão (and the Monte Abraão neighbourhood) in the Sintra municipality.

The results of the survey confirmed that the Angolans are highly concentrated in marginalized areas of the urban territory: over 50\% of the families of the descendants of Angolans and Luso-Angolans lived either in slums, social housing areas or run-down neighbourhoods.

The link between the area of residence and the level of social integration of the descendants of Angolans and Luso-Angolans has to do with the fact that social exclusion usually comes hand in hand with spatial exclusion. In this vicious cycle of exclusion, the run-down, unkempt urban environments in which the socially and economically excluded are concentrated often limit their prospects for upward social mobility and integration. In turn, the fact that there is such a high concentration of excluded populations in these areas brings about a decrease in the social and economic value of these parts of the urban territory. Conversely, living in areas that have a high social value can facilitate the upward social mobility of the individuals, while the spatial concentration of groups that have a high social and economic status tends to increase the economic valuation of these areas.

8 This indicator consists of the ratio between the weight of the Angolan citizens in the total population of each freguesia and the weight of the Angolan population in the total population of the LMA.

9 This neighbourhood - not unlike the Vale de Chícharos (a.k.a. Jamaica) neighbourhood in the Seixal municipality, whose characteristics are in many ways similar - originated as a consequence of the occupation of unfinished buildings and construction sites in the early 1980's. These unfinished buildings, lacking in sewage and any other equipment whatsoever, were gradually occupied by excluded populations, whose number grew as more and more immigrants kept arriving and settling in the neighbourhood. The original Quinta do Mocho neighbourhood was eventually demolished and its residents were subsequently rehoused in a new social housing neighbourhood. 


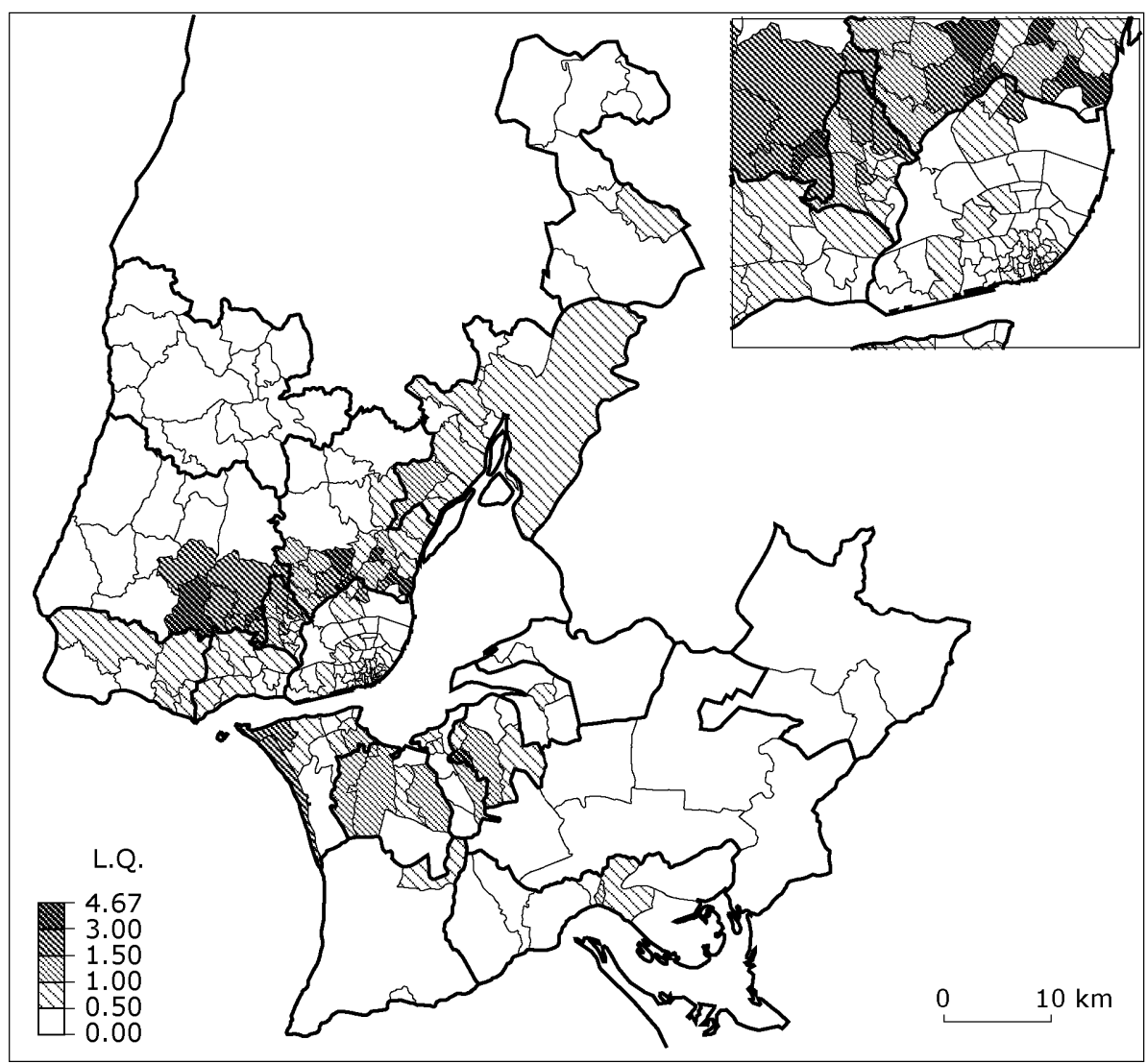

Source: INE, 2001 Population Census.

FONTE: INE, Censos 2001.

Figure 2 - Location Quotients of the Angolan Citizens Living in the LMA.

Figura 2 - Quocientes de localização dos indivíduos de nacionalidade angolana residentes na $A M L$.

Therefore, the analysis of the concentration of the families of Angolan origin in run-down, low-value urban areas should take two different aspects into account: on the one hand, the fact that it reflects their lack of resources, i.e., as an indicator of poverty, social exclusion and lack of access to equal opportunities; on the other, the very impact of the environment upon the individual. There is a very strong link between the characteristics of the physical space and those of the social environment: the former can either foster or hinder the "physical and psychological security of the individual, the establishment and maintenance of community ties, the appropriation and expression of feelings of affection with regard to the territory beyond the sphere of the household (...), 
the social and geographic mobility of the individual and the performance of daily activities..." (CABRITA et al., 1998: 162).

Shantytowns and the like (such as the Quinta do Mocho and Vale dos Chícharos neighbourhoods) offer the worst conditions of all in terms of housing and social environment. However, they are being gradually eradicated and shall continue to be so, as their residents are re-housed in social housing areas. Thanks to the PER ${ }^{10}$ and PER/Famílias Programmes ${ }^{11}$, the number of shantytowns in the LMA has decreased quite dramatically. Nevertheless, at the time of this survey, a significant number of families of Angolan descent still lived in slums and shanty neighbourhoods $(8.6 \%$ of the households that were included in the survey, which was carried out in 2000/2001 - see footnote 7).

On the other hand, the problems that have to do with housing and the urban environment do not necessarily cease to exist when people are given new houses in social housing neighbourhoods. Often, re-housing is seen as a mere issue of funding and construction, and the authorities frequently overlook the real problems of the people for whom the houses are intended. All this notwithstanding, there have indeed been some improvements in terms of infrastructure, facilities and quality of the public spaces in most cases, as well as several social integration and/or urban renewal programmes.

Even though social housing neighbourhoods obviously allow for better living conditions than shantytowns, there are several negative aspects to the models followed thus far that are worthy of mention. First of all, the spatial segregation that is implicit in these models: social housing neighbourhoods are usually located in peripheral areas of the city, far from - and loosely connected with - the rest of the urban fabric. This fact, which impinges upon the time spent going to work and back and accessing other services and facilities, is one of the reasons why these areas close themselves in to such an extent and why the residents of these areas have such low spatial mobility. Moreover, however remarkable some of the architectural designs may be (some have in fact won architectural awards), social housing neighbourhoods can usually be easily discerned from other neighbourhoods because of their monotonous and often excessively dense characteristics ${ }^{12}$. Social housing neighbourhoods are thus labelled as neighbourhoods of the poor and are subject to social and spatial discrimination. The quality of the finishing and of the construction materials is usually quite poor, which causes the buildings and facilities to quickly become run-down. The general image of these neighbourhoods is that of dense concrete

10 Special re-housing programme, implemented by the central government and the municipal authorities, in order to eradicate all shacks and to build new residential blocks up until the end of the year 2001.

11 PER Families, set up by Decree-Law 79/96, allows people living in shacks, to buy a house for permanent residence that is suitable for the size of the family or to restore a house they own elsewhere on condition that it will be used as the family's permanent residence.

12 However, it is worth stressing that collective housing has often played a very important role in meeting the most basic needs of the most vulnerable in emergency situations. 
jungles painted in one monotonous colour or, alternatively, in exceedingly bright colours (as is the case in the Bairro do Condado neighbourhood in Chelas, formerly known as Zona J), and with a permanently unfinished feel to them that is due to the lack of concern with the outside look of the buildings. Finally, these neighbourhoods more often than not lack in basic infrastructures and facilities, commerce and services.

The aforementioned coexistence of poor housing conditions and a series of social problems, such as unemployment, illiteracy, poverty, drug abuse, etc., can be found in most of these areas - whether they are shantytowns or social housing neighbourhoods. This renders the resident population of these areas especially vulnerable to social exclusion and addressism (for instance, by limiting their chances of finding a job or of maintaining social relations with people from outside the neighbourhood).

Moreover, ZHou (1997) argues that the high concentration of immigrants in these segregated and run-down neighbourhoods tends to foster the direct contact of the descendants of immigrants and ethnic minorities with the other unprivileged and marginalized groups that live in the same areas. Their social networks are thus limited from the start, while their expectations are shaped by a surrounding environment in which poverty and the lack of opportunities for upward social mobility are widespread. The social implications of living in a "poor people's area" - along with the lack of feelings of identification towards the neighbourhood and the difficulty of moving out - are indeed very serious. "Residents (...) often interiorise this label, not because they think of themselves as deviant, but because they absorb the general image of the neighbourhood and blame it on some of their neighbours (...) For many families, escaping this label represents an extraordinary effort that has very important consequences upon their behaviour and their investment in the neighbourhood" (GUERRA, 1994: 11).

However, we have found that most of the people interviewed claimed to like their area of residence, regardless of what that was. Nevertheless, as might be expected, there is a strong correlation between the characteristics of the neighbourhood and the percentage of people who claim to enjoy living there (in ascending order of satisfaction, from shantytowns to social housing areas to "normal" neighbourhoods), as well as between the former and the main reasons indicated as to why they enjoyed living there (in the case of the people that lived in shantytowns, these reasons included aspects having to do with the neighbours - e.g., "nice neighbours", "my friends also live here", as opposed to it being a "nice/beautiful" or "well-equipped" neighbourhood or having a "good/pleasant urban environment").

\section{Youth Culture and Identity}

The crisis of identity of the descendants of immigrants can create additional barriers to their successful integration. In this section, we seek to shed some light on the relationship between identity and integration. 
However, we should start by stressing that the relationship between these two aspects is not straightforward, even if it is true that the analysis of the issue of identity, along with other related aspects, can tell us something about integration ${ }^{13}$. In other words, we do not by any means mean to argue that just because an individual identifies himself as being an Angolan, he/she will automatically be poorly integrated into Portuguese society, nor that those identified as Portuguese do not experience social exclusion and marginalization. Rather, we seek to explore the extent to which the culture of a particular group can provide a link between identity and integration, insofar as it can act as a factor of resistance against society.

A culture of resistance and opposition to the wider society is most likely to be found in highly marginalized neighbourhoods in which people experience severe social problems. Living in areas in which most people are employed in highly precarious and unskilled activities, have low social status and in which there is daily contact with situations of alcohol and drug abuse is often a source of frustration for the residents of these areas.

The problems usually arise when the descendants of Angolans and LusoAngolans, who were born in the country or at least are not responsible for their presence in the country (and it is worth mentioning that our survey found that, when asked whether they felt Portuguese, Angolan, a mixture of the two, African, or some other thing, $51 \%$ of the individuals answered "Portuguese" and $36 \%$ answered "a mixture of the two") experience situations of unequal opportunities. Unlike their parents - whose standards are those of their country of origin and who therefore feel that they are better-off than they were before migrating, and better-off than their fellow countrymen who chose to stay in Angola - the references of the Angolan and Luso-Angolan children are those of the Portuguese middle-class. Having much greater expectations than their parents, they do not easily conform to being relegated to a social status well under the Portuguese average standard. Under such conditions, it is hardly surprising that feelings of reactive ethnicity arise, i.e., the emergence of a feeling of belonging that is fostered by being labelled against their will, subject to discrimination and described in a pejorative manner (PORTES, 1999).

It should be stressed that this culture of opposition is not an exclusive feature of the descendants of immigrants. In fact, it is quite common among other minority groups, including Portuguese youths that share the same social background. In this culture, certain symbolic elements of the African culture are recreated, reinvented and combined with elements from other sources, particularly the American ghetto culture. Indeed, the relationship between the residents and the areas in which they lead their daily lives is filled with symbolic

13 Identity is a flexible, dynamic concept that is related with the adoption of beliefs, practices and values that can be typical of a particular age, social or ethnic group, a particular territory (country, region or neighbourhood), and so forth. Moreover, since the latter are not mutually exclusive, an individual can assume multiple identities, even with regard to one single characteristic. 
elements that have to do with their cultural references, as well as with their strategies for changing both the surrounding environment and their own social and residential mobility" (PAIVA, 1997: 236). However, in the case of the descendants of African immigrants, this culture often builds on a feeling of rejection on the part of the wider society, which in turn is largely due to the effect of the media that promote an association between juvenile delinquency and black youths.

In these problem neighbourhoods, the most successful examples usually come from people that break the law in one way or the other. Consequently, illegal activities are seen by many young people as the only possible way to pull out of poverty.

We do not mean to deny the existence of a culture of violence ${ }^{14}$. However, it is important to distinguish it from the symbols adopted by the black youth culture (which in fact is not exclusively black): language, music, behaviour, aesthetics and fashion ${ }^{15}$.

The survey that we have conducted has shown that many young people of Angolan descent can speak Creole, even when they can not speak any Angolan dialect. This fact is confirmed by António Concorda Contador (1998; 2000), who argues that this type of Creole - which reinvents and incorporates elements and influences of other languages and cultures, e.g., the PALOP countries, the major American and European cities and their own neighbourhoods in Portugal - has eventually become an "urban slang dialect" that binds together this group of youths, the majority of whom are blacks but among whom some whites that live in the same areas can also be found. Thus, proficiency in the use of this specific type of Creole is a prerequisite for the integration of these youths in a group of peers and in the wider black youth culture.

This phenomenon is especially visible at a micro-scale, in areas where there is a high concentration of immigrants and descendants of immigrants and where social problems are usually most serious. However, this does not mean that there is a necessary relation between this type of social practice and violent or criminal behaviour.

To sum up, we argue that alongside citizenship as an identity factor, there is another important aspect of territorial identity in the case of these youths that is associated with the neighbourhood. This latter aspect of identity contains many elements of a black youth culture that is not specific to any particular nationality or community - rather, it consists of a selective mixture of various elements and influences. This specific culture does not necessarily become a barrier to integration. However, it can hinder the integration process, whenever

14 The percentage of Africans among the inmate population is very high, especially among the youths. In particular, the Africans in the 19-24 age group are responsible for a significant share of the criminal behaviour (Justino et al., 1998).

15 Contador (2000) argues that this black youth culture is an identitarian "middle ground" that is the result of a mixture of three different influences: Portuguese culture, African culture and blackness. 
the degree of opposition to the wider society (which typically depends on the social problems and environment of the neighbourhood) is too high, or whenever certain individual cases of juvenile delinquency are associated with the group as a whole.

\section{School Behaviour and Performance}

Considering that most descendants of immigrants are quite young, the school is the obvious place to assess their level of adaptation and integration in the host society. Indeed, differences in school performance and in adapting to school life reflect present and future differences in social and economic integration. Moreover, school performance is also a good indicator of the future professional mobility and of the likelihood of success in the long run. Therefore, the current differences in school performance between students of different nationalities provide an indication of potential differences in their future social and economic integration (PORTES; MACLEOD, 1999).

By analysing the data from the Entreculturas ${ }^{16}$ database, made available by the Ministry of Education, we are drawn to the conclusion that the level of school failure and drop-out is much higher among the students of the Angolan community - and the other five PALOP communities - than the average for the Portuguese student community as a whole. Our survey has confirmed that, at every level of schooling, the percentage of students that have already dropped out or failed at least a year is indeed quite significant. That is especially the case in high school and university: as an example, roughly $70 \%$ of those students included in the survey that were enrolled in the $9^{\text {th }}$ grade were over the age of 15, which implies a worse than average school performance.

Still, according to both our own data and the "Portugal Multicultural" survey (BASTOS, 1999), it seems that the average performance of the Angolans is somewhat better than those of the Santomese, Guineans and Cape Verdeans (the latter being particularly worrisome), even if they come out losing when compared to the Mozambicans and the students of Portuguese descent.

A distinction should be made between two aspects that are different school performance and behaviour at school, despite their strong correlation. A series of interviews to teachers allowed for the following findings:

a) In what regards behaviour and discipline (bearing in mind that these rough generalisations conceal the internal variety within the group):

- references were made to the length of the stay in the country: the students that have recently arrived in Portugal seldom create problems

16 This source, very much like our own survey, takes the family origin of the students - a broader criteria than either citizenship or the place of birth - as the criteria for defining the various ethnic-social groups. It is therefore the official source whose methodology comes the closest to our own. However, private schools and universities are left out by this source, and not all failure and drop-out rates are made available. 
of discipline, even if their difficulties in adapting translate into their poor school performance; it is the youths that either were born in the country or have been here since they were little (i.e., the group defined earlier on in this paper as the "descendants of Angolans") that are considered to be most problematic;

- several teachers have stated that, contrary to common wisdom, the worst problems in terms of discipline come from students of Portuguese descent that live in neighbourhoods that have severe social problems (in which large numbers of Africans usually live as well) - not from the actual descendants of immigrants.

b) With regard to school performance, one of the factors that may explain the relative success of the Angolan youths (when compared to those of other PALOP communities, particularly the Cape Verdeans ${ }^{17}$ ) is their relative proficiency in the Portuguese language. Most descendants of Angolans are native speakers of Portuguese - the predominant language in the urban areas from which most of them originate - and can not speak any other Angolan dialect.

\section{Integration in the Labour Market}

The professional status and the characteristics of the participation of the Angolans and Luso-Angolans in the labour market provide yet another good indication of their integration in the Portuguese society. Due to the fact that our survey was conducted in schools ${ }^{18}$, we are unable to provide an in-depth analysis of the professional characteristics of these individuals, based solely on this element of research. However, the answers to some of the questions in our questionnaire, along with the opinions expressed by some representatives of schools and community associations, allow for a qualitative approach to this issue.

Generally speaking, the future prospects and expectations of the students that live in areas afflicted by social, economic and territorial exclusion are usually very limited and are constrained by the surrounding environment. The President of the Board of the "Ana de Castro Osório" Middle School, which is located in the Belavista neighbourhood in the Setúbal municipality (a social housing area with serious problems of social exclusion), maintains that the reason why many of the students of this school do not pursue their studies any further than $9^{\text {th }}$ grade has to do with the fact that most of them have over time

17 It is worth pointing out that the average Portuguese language skills of the members of the Cape Verdean community are indeed quite limited - often, even in the case of those that were born in Portugal -, which creates additional barriers to their successful school performance.

18 A few workers have been interviewed, but with the sole aim of helping to characterise the descendants' sub-group. 
been convinced that they will inescapably work in either construction or house cleaning.

Still, this is not an inevitable scenario. The activities of the SOS - Association for the Defence of Angolans - an Angolans' association that originated in the Quinta Grande neighbourhood (a former shantytown in the Charneca freguesia, in the municipality of Lisbon) - provide an interesting example. This association has been working with the local population for some time in the area of education, by providing school counselling and support and by negotiating the access to scholarships and placements in both public and private universities. According to a representative of this association, after the first local resident (a young man formerly employed in construction) succeeded in entering university, the number of local youths that have decided to further pursue their education has increased considerably.

Nevertheless, both school teachers and representatives of the community associations agree that the general tendency is for the social and professional profile of the descendants of Angolans to remain more or less unaltered in the future.

Some of the findings of our survey also support this idea. Among the 429 descendants of Angolans covered by the survey, some were active and/or student workers. Their number (39 active, 14 student workers) is not large enough to enable us to draw general conclusions, but the fact is that the jobs and occupations that we did find show little signs of a change in the social-professional profile that we have previously described. On the one hand, we did find a group of individuals that performed slightly more skilled activities, but, on the other, we found a much more numerous group (64.6\% of the answers) working in unskilled activity sectors. However, it is interesting to note that the latter seem to prefer to perform activities that are different from those of their parents, either in commerce (working as clerks and handymen, both in large department stores and in traditional shops) or in restaurants and cafés.

Except for the case of an actress that was also pursuing her university degree, all the other student workers whom we have interviewed performed unskilled professional activities such as handing out publicity materials or working in call-centres, usually in a "spirit of part-time".

Still, when asked which jobs they would like to have in the future, almost? of the descendants of Angolans included in the survey indicate jobs that require an university degree. Medical practice stands out from among a wide variety of preferences. Professional football and the performing arts (particularly the music world) were also quite common dreams among the teenagers in this group. The small number of individuals that claimed to prefer unskilled activities was on average slightly older than the others. However, it should be stressed that this particular question sought to identify those jobs that these youths would like to have in the future, not the ones that they think they will have. 


\section{CONCLUDING REMARKS}

The analysis of a series of indicators - namely the area of residence, school performance, prospects/expectations with regard to the future participation in the labour market and the relationship between identity and the culture of opposition - confirms that there are widespread difficulties and problems of integration among the individuals in this group.

The descendants of Angolans and Luso-Angolans are clearly over-represented in run-down, marginalized areas and in social housing and shanty neighbourhoods. In this paper, we have analysed this fact, bearing in mind that social and spatial exclusion are strongly associated and reinforce one another. Therefore, the area of residence is both an indicator of their economic needs and lack of resources, and an important constraining factor that acts upon the individuals by lowering the expectations of the youths. In other words, territorial exclusion is the reflection of a series of factors that hinder successful integration.

We have also found that the descendants of Angolans tend to have a high level of involvement in neighbourhood group activities that are characteristic of a certain black youth culture. Whenever the autochthonous population associates this culture with deviant or criminal behaviour, or whenever its component of opposition to the rest of society is very significant, it poses additional barriers to their successful integration, while at the same time being a symptom of their previous failures in this field.

The findings of our survey have also confirmed the existence of high levels of school failure among this population sub-group. This eventually translates into low levels of schooling and jeopardizes any chances of upward professional mobility as compared to their parents' generation.

In spite of the relevance and intensity of these general facts and trends, one should bear in mind that any general analysis conceals the individual differences that exist within the group and which, in this case, are the result of a combination of the variety of factors that influence the individual's process of integration. Indeed, some individual cases do provide exceptions to this general picture: we were able to find a number of descendants of Angolans whose families lived in relatively wealthy areas of the Metropolitan Area, whose parents had jobs that had relatively high social status and whose lives thus far showed no reasons for concern in what regards their future integration in the Portuguese society.

Finally, we would like to add that this research has enabled us to confirm that the level of awareness in the Portuguese society with regard to the descendants of immigrants is indeed quite limited. At a time when pluralism and the equality of rights and opportunities are such important values, and when there is an urgent need to design and implement effective strategies to deal with the existing problems in this field and to prevent the emergence of new ones, this fact should be a serious cause for concern. It is hard to tackle the factors that hinder successful integration, if one does not know what those very factors are. 
This paper seeks to provide a contribution to helping increase the level of awareness regarding these individuals and their community, but further research is definitely necessary both in the case of this particular community and in those of other descendants of immigrants.

We have sought to draw some conclusions that will hopefully prove useful in understanding the issues that are involved in the process of integration of the descendants of immigrants in the Portuguese society, and we have placed a special emphasis on the Angolan community. Even though we are convinced that we have achieved this goal, we are also aware of the fact that this subject is far from fully known and understood, and hope that some of the clues that are put forward in this paper will be subject to further research.

\section{REFERENCES}

Albuquerque, Rosana; Ferreira, Lígia E.; Viegas, Telma (2000) - O Fenómeno Associativo em Contexto Migratório: Duas Décadas de Associativismo de Imigrantes em Portugal. Celta Editora, Oeiras.

Baganha, Maria Ioannis; Ferrão, João; Malheiros, Jorge (coord.) (2002) - Os Movimentos Migratórios Externos e a sua Incidência no Mercado de Trabalho em Portugal. "Estudos e Análises" 14. Observatório do Emprego e Formação Profissional, Lisboa.

CABrita, A. M. R. et al. (1998) - Análise e avaliação da qualidade habitacional. Sociedade e Território, n. ${ }^{\text {os }}$ 25-26, Edições Afrontamento, Porto: 162-170.

Contador, António Concorda (1998) - Consciência de Geração e Etnicidade. Sociologia-Problemas e Práticas, n. $^{\circ}$ 26, Celta Editora, Oeiras: 57-83.

Contador, António Concorda (2000) - Cultura Juvenil Negra em Portugal. Celta Editora, Oeiras.

GUERRA, Isabel (1994) - As pessoas não são coisas que se ponham em gavetas. Sociedade e Território, n. ${ }^{\circ} 20$, Edições Afrontamento, Porto.

Justino, D.; Marques, M. M.; Ralha, T.; Palácio, S.; Seabra, H. (1998) - Children of immigrants: a situation in flux between tension and integration. SociNova, Working Papers 7 (mimeo).

Machado, Fernando Luís (1994) - Luso-africanos em Portugal: nas margens da etnicidade. Sociologia-Problemas e Práticas, n. ${ }^{\circ}$ 16, Celta Editora, Oeiras: 111-134.

PoRTES, Alejandro (1997) - Divergent Destinies: Immigration, the Second Generation, and the Rise of Transnational Communities. SociNova, Working Papers 1 (mimeo).

PoRTES, Alejandro (1999) - Migrações Internacionais - Origens, Tipos e Modos de Incorporação. Celta Editora, Oeiras.

Portes, Alejandro; MacLeod, Dag. (1999) - Educating the Second Generation: determinants of academic achievement among children of immigrants in the United States. Journal of Ethnic and Migration Studies, 25(3): 373-396.

Rocha-Trindade, M. B. (1995) - Sociologia das Migrações. Universidade Aberta, Lisboa.

ZHou, Min (1997) - Segmented assimilation: issues controversies and recent research on the new second generation. International Migration Review, 31(4): 975-1003. 